in the biological laboratory at South Kensington, and, after a diligent attendance at Prof. Huxley's eighty odd lectures, and at the five months' practical work, he succeeded in passing the examination in the second class. The two following years Mr. McAlpine, with laudable perseverance, again presented himself for examination, each time appearing a place or two lower in the second class.

While working at South Kensington Mr. McAlpine made several copies of the diagrams of type dissections in the laboratory, which diagrams are for the most part enlargements of my original drawings made by my friend and former colleague, $\mathrm{Mr}$. G. B. Howes. I naturally imagined that Mr. McAlpine, like other students who had taken the same trouble, intended to use these copies either for his private work or for his classes in Edinburgh, and I was, therefore, greatly surprised at the appearance of the Biological Atlas, to find in it a number of marvelJously inaccurate copies of these same diagrams, published not only without permission, but without the slightest reference to their source even in the preface.

In the Zoological Atlas (Vertebrata) the same thing occurs, and my diagrams, although strangely altered, are quite recognisable; in the figure of the skate's nervous system, for instance, I notice, copied with unusual accuracy, a mistake as to the origin of the orbito-nasal nerve, which occurred in my original drawing, but which has subsequently been corrected.

In the cases where Mr. McAlpine, having no diagrams to copy, has had to depend upon his own dissections and the statements in text-books, the results are sometimes remarkable. As an instance, I may take the ingenious diagram of the skate's vascular system, in which paired caudal veins are shown accompanying the caudal artery, and passing directly into the corresponding cardinal veins, the renal portal systems being completely suppressed.

According to the adverticements, the Athencum recommends the "Biological Atlas" to all students of the subject; I regret that I cannot agree with ycur contemporary; in my opinion no books could possibly be more mischievons to a beginner than these, since they hold up for his example and imitation a work of the most inaccurate and slovenly description; as indeed, if possessed of ordinary powers of observation, he camnot fail to find out for himself before he has been a month at the subject.

$$
\text { T. JEFFERY PARKER }
$$

Otago University Museum, Dunedin, N.Z., March 24

\section{Palæolithic Implements-New Localities in the Thames Valley, near London}

In NAture, for July I 5, 1880, p. 253, Mr. P. H. Pepys drew attention to a section then being made through beds of river gravel and brick earth near the West Drayton Station of the Great Western Railway. I had an opportunity of going to West Drayton on July 27, I880, so I walked through the cutting towards Langley. My quest was for relics of primæval man, and I was rewarded by finding not only several fint flakes, but the butt end of a massive implement broken in Palæolithic times. This was just north of Langley Station, in Buckinghamshire, and the first Palrolithic relics, as far as I know, detected in that county. The workmen in the cutting for the new canal were such $\mathbf{a}$ rough lot that $I$ found it impossible to fraternise with them, so my subsequent visits were all made on Sundays. During these walks I lighted on ten implements ano a large number of flakes at Langley and Iver, all in the valley of the CoIn, and a river until now (as far as I know) not described as implementiferous. In gravel brought from the pit close to Taplow Station I found a single implement, a large trimmed flake, and numerous simple flakes; this position is alvo in the county of Buckingham. At West Drayton, in Middlesex, in the valley of the Coln, I lighted on five implements and numerous flakes. East of West Drayton, in a pit near Botwell, in the valley of the Yedding Brook, hitherto undescribed as implement-bearing, I found a single implement; this was in the pit near Bull's Bridge. In the same valley at Hillington, and other places I have found several other implements. In all the excavations from Slough to Acton I bave found both implements and flakes. In the new railway cutting from Gunnersbury to Hounslow I have found four implements, one close to Hounslow, a massive butt, and many flakes. This cutting has been a very interesting one, from the abundance of the fossil shells of fresh-water molluscs found in the sands, especially near the bridge under the Hanwell Road. One shell very abundant, and, as far as my observation goes, absent from the sands of
North.east London, is Achatina acicula, Müll., kindly named for me by Dr. J. Gwyn Jeffreys. I believe this is the first record of fre:h-water shells from the Paleolithic sands of the Ealing district. Since my paper on the Valley of the Brent was read before the Anthropological Institute, in June, I879, I have found many more implements in the positions there mentioned. At North-east London, and especially in the Valley of the Lea, I have been able to greatly extend the range of Palæolithic man. In addition to the localities mentioned in my paper read before the Anthropological Institute, in June, 1878, and published in February, 1879, I am now able to mention London Fields, Homerton, in the south, a position south of Dalston Junction, and nearer the Thames than the places first given by me, Hackney, near the railway station, Abney Park Cemetery, South Hornsey, Highbury, Stamford Hill, Upper Edmonton, Lower Edmonton, Bush Hill Park, Forty Hill, Enfield, and Cheshunt; the pit at the last place, which formerly produced flakes only, has since furnished three implements-one an example of the first class. On the east side of the Lea I have found implements in the gravels of Stratford, Leyton, Leytonstone, Wanstead, Walthamstow, and Higham Hill-a magnificent example from the last place. Further east, and in the Valley of the Roding (first pointed out by me as a river bearing implements in its gravels - at Barking- I have found two implements, and elsewhere in the neighbourhood, as at Ilford and Upton, numerous flakes. Still further east, at Gray's Thurrock, West Tilbury, and Southend, I have evidence of the presence of primæval man; at the latter place, a rude malie-shift implement, and a scrapingtool with twin bulbs of percussion. These were found by my two sons. I have not mentioned all the positi ns I know in this letter, or re-mentioned those given in my two papers, but rather the positions I can afford to dispense with. It shows, however, eipecially when considered with the discoveries at Reading and Oxford, what a vast cohort of men once lived all along the Thames and its northern tributaries in Palæolithic times.

125, Grosvenor Road, Highbury, N.

WORTHINGTON G. SMITH

\section{"Halo": Pink Rainbow}

THE appearance noted in NATURE this week (p. 268) by Prof. O'Reilly must surely have been a case of the rayons du crépuscule that are frequently vi-ible near sundown in the eastern sky. East-south-east cannot at this season be very far from opposite the setting sun. Prof. O'Reilly does not mention, though probably it was the case, that the point of convergence of the "beams" which he saw was diametrically opposite the sun's position. That these beams appeared dark is probably merely caused by the real "rayons" being wide, with narrow, darker interspaces between. I have several times (sfe Fhil. $M a g .$, I 877$)$ called attention to the existence of similar rays crossing the rainbow radially; indeed, it is seldom that a rainbow occurs when the sun is low in the sky, without one or more such rays being visible within the arc. Two such rays, for example, were visible in a bow seen here at sunset two evenings ago. This bow was interesting in another way al:o; for, like the "pink" rainbows about which there was some correspondence in NATURE last year, the only colours visible (in the primary arc) were red and yellow, the red being of a pinkish rather than a crimson hue.

Pollokshields, Glasgow, July 20

\section{Smoke Abatement}

Count RumFord founded the Royal Institution of Great Britain nearly a hundred years ago, chiefly, I helieve, to introduce improved grates, fireplaces, stoves, \&c., as he then foresaw the necessity of economising coal and obtaining more complete combustion.

In about the year I860 Faraday himself showed me Count Rumford's models, \&c., and some of Rumford's working stoves in the model room in the Institution, a subject in which I was then much interested, as I was enlarging my own house.

About ten years ago, when the laboratory of the Royal Institution was enlarged, the models, stoves, \&c., devised by Count Rumford were removed. It would be important to know what has become of them. Would you kindly allow me to ask this question?

July 19
A Member of the Royal Institution 